\title{
TRACING THE LIFE AND WORK OF AUGUST ROZENTAL
}

\author{
LECH JACZYNOWSKI \\ Józef Piłsudski University of Physical Education in Warsaw, \\ Faculty of Physical Education and Sport in Biała Podlaska, Chair of Tourism, Department of Management
}

\author{
Mailing address: Lech Jaczynowski, Faculty of Physical Education and Sport, Department of Management, \\ 2 Akademicka Street, 21-500 Biała Podlaska, tel.: +48 83 3428784, fax: +48 83 3428800, \\ e-mail: lech.jaczynowski@awf.edu.pl
}

\begin{abstract}
Introduction. The objective of this paper was to provide an overview of the life and work of a Polish artist and painter, August Rozental, who lived and worked in Bulgaria in the late $19^{\text {th }}$ and early $20^{\text {th }}$ century and is completely unknown in Poland. Documentation of his work may be of interest to both art historians and Polish travel agencies, the latter for marketing purposes. Material and methods. In searching for reliable information, the focus remained on historical, iconographic and epigraphic sources. Archival and museum collections were consulted, as were academic libraries, periodicals and internet sites (Polish, Bulgarian, Serbian and Russian). The information thus obtained was verified on the basis of three interviews with museology specialists. Results. The information was presented in terms of a description of the location and marketing product, to address the needs of cultural tourism. Consequently, the descriptions focus primarily on the artist's surviving works and their locations in monasteries in and around Sofia. Along the way, interesting information was discovered regarding the accomplishments of his brother Juliusz, a poet, and their father August, a doctor who years earlier was exiled to Siberia along with his family. Original, newly discovered documents containing personal information about August Rozental (the painter) are also presented. Conclusion. The research confirms his Polish origins and documents the current locations of his most interesting works of art. This makes them easily accessible to both specialists and tourists interested in the subject.
\end{abstract}

Key words: tourism, marketing, religious painting, art history, polonica, Siberia, Balkans

\section{Introduction}

In March 2013 a Bulgarian television station broadcasted a program on the Alexander Nevsky Orthodox Cathedral in Sofia (fig. 1). This is the largest orthodox church in the Balkans and one of the largest in the world. During the program, a Polish painter was mentioned several times by name: August Rozental (Avgust Rozental), who belonged to a group of that period's most eminent artists (primarily Russian and Bulgarian) who were charged with decorating the cathedral. Members of this group developed a conception in the late $19^{\text {th }}$ and early $20^{\text {th }}$ century, which they then applied in decorating the cathedral (frescos, mosaics, tympana and iconostasis), a church that doubled as a monument of gratitude for Bulgaria's liberation from five hundred years of Ottoman rule.

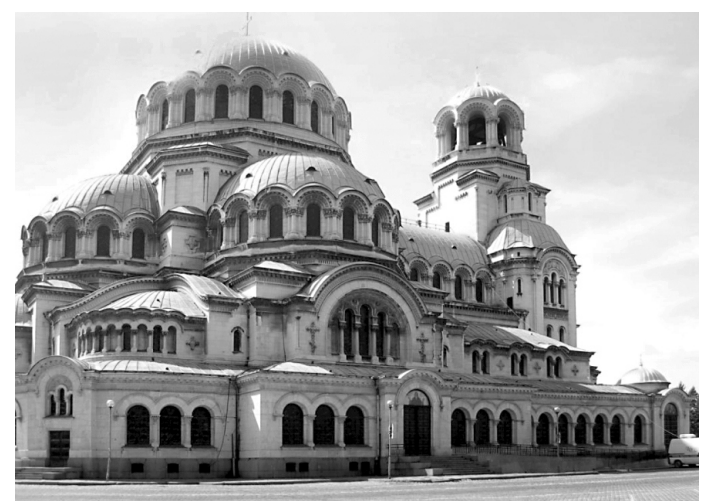

Figure 1. Alexander Nevsky Cathedral in Sofia (photo by author)
Attempts to obtain information on this Polish painter from Polish sources (encyclopedias, the internet, the Dictionary of Polish Artists) proved fruitless, as did inquiries at the Academy of Fine Arts in Warsaw. Granted, research at the AFA Library did turn up information on an August Rozenthal, but this German landscape artist worked in a different region, his surname is spelled differently and, most importantly, he died in 1875, precisely the year our protagonist was born. No record of Rozental is to be found in the works of Kaczmarek [1], Klejn [2] or Wasilewski [3], Polish authors who specialize in describing the historical conditions underlying Polish-Bulgarian relations. Thus, the decision was made to see what information could be found in Bulgaria itself. Such information could be of interest not only to art historians, but also to travel agencies; when organizing trips to Bulgaria, agencies could expand their offer to include information on the physical traces left behind by eminent Poles, whose fates led them there, and whose achievements contributed to the country's history.

\section{Material and methods}

The objective of this paper was to provide an overview of the life and work of a Polish artist and painter, August Rozental, who is completely unknown in Poland. The research primarily involved searching for sources of information on his work and Polish origins. The focus was on historiographic, iconographic and epigraphic sources. The search for written sources involved archives, academic libraries, periodicals and websites (Polish, Bulgarian, Serbian and Russian). Collections in museums, galleries, orthodox churches and monasteries were examined. This information was supplemented by interviews with managers 
from three different institutions (involved in documenting historical information), who were qualified to discuss the sources that interested us. As a result, the information thus obtained is of both a primary and secondary character.

The abovementioned research was oriented towards a description of the location and marketing product, to address the needs of cultural tourism [4]. At the same time, answers to the following research questions were sought:

1. What reasons are there for believing that August Rozental was of Polish extraction?

2. Where are the sources of information on this figure located?

3. What works did this painter create, and where can they be accessed?

Due to the heterogeneous and hence interdisciplinary nature of the research, an attempt was made to obtain source information about August Rozental that is unknown in Poland and that may be of interest to:

- specialists in the history of culture who, having been given information on specific works and where they are exhibited, will now be able to catalog and analyze them in terms of artistic merit;

- historians specializing in the Polish émigré community, whose representatives boast significant achievements abroad, making them into true ambassadors of Polish culture in foreign lands;

- social psychologists will surely be interested in the fact that Polish society lacks rational criteria for determining whether someone is a countryman or not;

- linguists interested in the principles underlying the transcription, transliteration and Polonization of foreign names, and in the heterogeneous application of these principles in cartographic studies.

Because the research was conducted in a region where the official alphabet is Cyrillic, citations from bibliographic sources were consistently transliterated in accordance with International Standard ISO 9:1995, a convention officially observed in Polish academic libraries under NP ISO 9:2000. With regard to place names, transcriptions found on international maps were used, in order to make it possible for potential tourists to find the locations using satellite navigation systems (GPS). The list of Polonicized geographic names and the principles for Latinizing Bulgarian geographic names, published by the Commission on Standardization of Geographical Names, were also consulted. In the text, Polonicized names were used whenever possible. However, depending on the situation, the first time a name or surname appears, it is given in the original Cyrillic, with the transcription or transliteration provided in parentheses [Translator's note: in the English version, Anglicized names are given first, with Cyrillic transcriptions provided in parentheses where differences occur].

The citation system employed in this paper is the Vancouver System, which was chosen due to the profile of the periodical. A considerable portion of the research was conducted in July and August of 2013.

\section{Results}

\section{Locating sources}

Because the first lead concerning August Rozental led to the Alexander Nevsky cathedral, the research began there. Conversations with local clergy contributed little to the investigation. They were rather poorly informed on who was responsible for what painting in the church. They explained that they had only recently been transferred there and had yet to master this subject. However, they did suggest contacting the National Orthodox Museum (Nacionelen c"rkoven muzej) operated by the
Episcopate (Svetiâ Sinod). Several visits and conversations with Georgi Mikov, the curator of this museum, finally bore fruit. Among other things, he helped search the local archives and navigate the Bulgarian internet [5]. But his most important contribution was to suggest searching the archives of the local Academy of Fine Arts (Nacionalna hudožestvena academiâ). This college was founded in 1896 as the National Drafting School (D"ržavno risuvatelno učilište). Access to books that were nearly 120-years-old required special permission from the current rector Prof. Svetoslav Kokalov, which in any case was obtained without difficulty. And here a kind of success was finally achieved. In a volume containing students' personal data and ID numbers for the first round of admissions in 1896 [6], the first entry featured complete information on our protagonist (fig. 2). Crumbling paper serves as a priceless source for documenting the reality of information heard more or less accidentally. The record suggests that August Rozental (Avgust Rozental) was admitted on September 22, 1896 to the first year of fulltime studies. He was born on December 15, 1875 in Irkutsk Russia and held Bulgarian citizenship, but was a Polish national and a catholic. The source further indicates that his father, also named August Rozental, was no longer living, and that he was supported by his mother Maria Piaskowicka (Mariâ Piaskovicka), a midwife (babuvane) living in Grabrovo. The document contains a description of the course of a three-year study program, a one-year pedagogical course entitling him to teach drawing in schools, and a two-year specialization in painting (he completed the latter in 1909). At the bottom of the document is Rozental's handwritten confirmation of having received the documents upon completing his studies in 1899, along with his beautifully calligraphed signature (in Cyrillic).

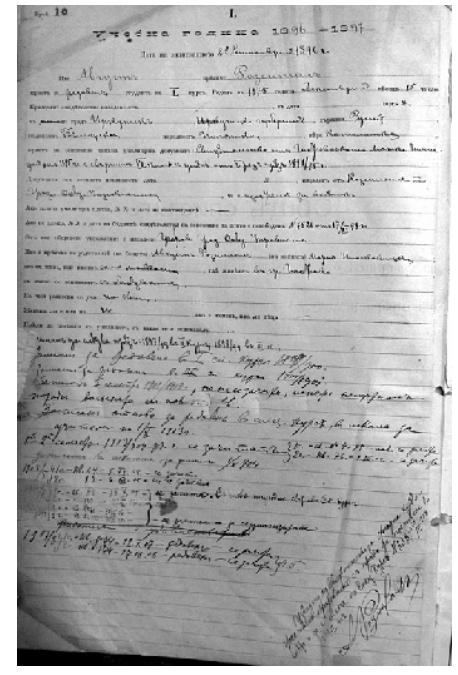

Figure 2. August Rozental's personal data from the DRU student registry for the academic year 1896-1897 (photo by author)

With the conviction (thanks to the abovementioned document) that the right trail had been found, routine investigations were begun at: the National Library in Sofia (Nacionalna biblioteka v Sofiâ), the library of the Bulgarian Academy of Sciences (biblioteka na B"lgarska akademiâ na naukite), local periodicals and the Bulgarian internet. It turned out that August Rozental, in the hundred years since his death, has hardly been forgotten there. Articles describing his turbulent life appear regularly. Unfortunately, many of them are gossipy and largely unreliable. That he was part of the local bohemia may well be true, but his capers with a prostitute who blackmailed him for years [7], or the claim that he designed a flying bicycle [8] seem 
rather like journalists' attempts at sensationalism. Other publications contain information about his works $[9,10,11,12,13$, $14,15,16,17]$, the fate of his father $[11,16,17,18,19,20]$, his brother's revolutionary and resistance activities $[11,16,17,18$, 19], etc. This information was verified by comparison with the memoirs of August Rozental's wife, Rajna Kostenceva, published in book form as My Hometown Sofia at the End of the $19^{\text {th }}$ and Beginning of the $20^{\text {th }}$ Century [11].

This book paints a picture of a Polish family exiled to Siberia, whose members try to find a place for themselves in a land far from their enslaved fatherland. A family actively participating in the social life of their new environment. Outstanding figures distinguishing themselves in their professions, ultimately giving their lives for their new fatherland, Bulgaria.

The painter's forefathers were probably still living in the Kingdom of Bohemia in the $16^{\text {th }}$ century, and their name was spelled Rožmitál. Following Emperor Ferdinand II's victory at the Battle of White Mountain in 1620, the Czechs lost their independence and became a hereditary land of the Habsburgs, and the local population was subject to repression and Germanization [19, 21]. The Rozental family fled to Poland and became gradually Polonized. After the November uprising of 1831, when a significant part of their property was taken from them, they settled in the Kiev province (in the village of Volniânska). And here, more or less, begins the documentation of the history of the father and his two sons: the poet Juliusz and the painter August.

\section{The father}

Here is a figure every bit as interesting as his son - the protagonist of our investigation. He was born in 1828 and spent his early years in Kiev. At the age of 16 he graduated from high school and began studying medicine at the University of Kiev. He obtained a doctor's diploma at the age of 21. Somewhat earlier, at the age of 18, he published a novel entitled Newlyweds (Nowożeńcy in Polish, Mladožencite in Hungarian) and a book of poems entitled Crown of Thorns (Cierniowa korona / Tr"nen venec), both in Polish. These titles are translated from the Bulgarian. A search for his works at the National Library in Warsaw yielded no results. This information comes from an introduction by Radka Penčeva to a collection of Bulgarian poems entitled Songs Half Sung (Niedośpiewane pieśni / Nedopeti pesni) by the second son, Juliusz Rozental (Û́lij Rozental) [16], as well as from a conversation with the previously mentioned authoress of the preface to the book.

August Sr. had a rebellious nature, and his opinions are characterized by certain commentators as anarchistic. Many publications report that he was a Polish nobleman and attach the title "von" (fon) to his surname. This information is challenged by his daughter-in-law, Kostenceva [11], who in writing about him emphasizes that he had liberal rather than anarchistic views and never attached any noble titles to his surname.

In 1854 he freed his serfs, which at the time was no longer something unusual. However, he publicized this fact, calling on the Polish nobility not to rely on the Tsar's government, but rather to free their serfs individually and of their own accord. He also participated actively in organizing a Ukrainian peasant revolt, for which he was sentenced to death. The sentence was ultimately commuted to Siberian exile, and in 1855 August Rozental and his wife traveled to Irkutsk, where they would remain until 1880. It was here that their children were born. Various sources speak of three sons and three daughters [16, 17, 20, 23], but Kostenceva [11] writes only of two sons - the elder Juliusz and the younger August - making no mention of other children.

August Sr. practiced medicine in his place of exile and deep- ened his knowledge of traditional Chinese medicine. After being released from exile, the family, bereft of its property, had nowhere and nothing to return to. The sympathy that the elder Rozental had harbored for members of the Brotherhood of Saints Cyril and Methodius (Kirilo-Metodievskoto družestwo) during his medical studies may have influenced his decision to travel to the Balkans. And on this point the Bulgarian sources differ once again. Some report that the Rozental family traveled to Plovdiv immediately, others that they settled first in Belgrade (Beograd), Serbia [19, 23]. The local authorities there accused the father, August Rozental, of practicing medicine without a diploma and of performing strange procedures (which today we would term physiotherapy). During the trial he is supposed to have shouted "...I'm neither a cheat nor a Jew, but a Pole and a catholic who obtained his medical diploma in Kiev and had it taken from him for political reasons before being exiled to Siberia." However, the trial ended with a hefty fine to be paid and an order to leave Siberia [19, 23]. In Bulgaria the family lived in various towns. First in Plovdiv, then Gabrovo, and finally Sofia (Sofiâ). It was here that Rozental established ties with the anarchist groups surrounding Spiro Gulabchev (Spiro Gulapčev) [24]. This led to a conflict between him and the current Premiere, Alexander Stambolov (Aleksand"r Stambolov). As punishment, he was sent to Vranje (present-day Serbia), where he was supposed to help Bulgarian soldiers who were stationed there fight a typhus epidemic. Unfortunately, while treating the sick he himself contracted the disease and died, most likely in 1888 (there is no precision in the sources concerning this date).

\section{The brother}

Our protagonist's older brother, Juliusz Cezar Rozental, was born in Irkutsk on July 14, 1872. Once the family had settled in Bulgaria, he graduated from the renowned high school in Gabrovo. His younger brother August would later attend the same school.

After Juliusz completed his education he began working as a teacher, first in the village of Kilifarevo, then in the village of Letnica. Like his father, he held radically liberal views. He became a member of the insurgent group that fought during the Ilinden-Preobrazhenie Uprising (Ilindensko-Preobraženskoto v"stanie) in 1903, which sought to liberate Macedonia - viewed at the time as a historical part of Bulgaria - from Turkish rule. Juliusz died in combat in the vicinity of the village of Lukovo on September 12, 1903. After his death A. Strašimirov, a former classmate, described Juliusz's fate in the introduction to the first edition of a collection of poems. This introduction was also included in the previously cited second edition, published in 2010 [16]. It is quite detailed and refers to various sources. It also explicitly confirms that the slender young man with blond hair and blue eyes was of Polish extraction.

\section{The wife}

August Rozental had but one love in his short life. This was the already mentioned Rajna Kostenceva, daughter of the owner of the first bookstore to open in Sofia after the liberation of Bulgaria. He was head over heels in love with her - so much so that he began signing his pictures with his surname and hers: August Rajna (Avgust Rajna). He drew and painted her countless times, using her as a model for his paintings.

She herself, in describing her relationship with August, recalls that at first she even went out of her way to avoid him [11]. She also writes that at the time "...I had no intention of falling in love with anyone, much less someone so utterly insane." They grew close while working at various schools in Dobrič ${ }^{*}$, where all of the teachers would meet together for meals in the

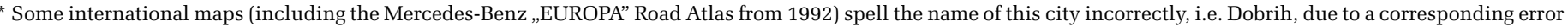
in the Cyrillic spelling [25]. 
same eatery. They married upon returning to Sofia, and August changed drastically under his wife's influence. He calmed down, stopped being absent-minded. "In order to paint my portrait," writes Rajna, "he did around 40 studies for the finished painting." He was such a master of perspective that many made use of his skills, first his friends at college and later artists that were already famous. He often gave away his work, when someone showed an interest in one of his canvases. Because of this, he often starved. But after the wedding, his wife took over the finances and the giveaways ended. In describing her husband, Rajna limits her-self to superlatives, “...he was as strong as an athlete and as delicate as a child. He was talented and extremely modest. He could fight for truth like a lion, but would become docile in the face of something good. He had a great Slavic soul in the full sense of the phrase. To demonstrate his strength he would hold up his arms and tell two people to hang from them, and he could sustain the weight. His physique was harmonious and his face had a classical appearance: a straight nose, high forehead, azure eyes, delicate features and curly hair. And he never got sick" [11].

Rajna's fate following her husband's death could hardly be called good. She married again, this time to a German artist named M. Metzgera (M. Mecger), whose personality differed markedly from August's, and who joined the NSDAP (for which he was ignored in Bulgaria after the war). Finally, in 1933 he left Rajna and moved to Germany. She preserved August's best paintings in her apartment at 125 Rakowski St. However, during allied bombing of Sofia in WWII, her house was hit and all of the canvases burned. Rajna died in solitude and poverty [7]. Nor do we know anything of the subsequent fate of the painter's son (also named August).

\section{August and his works}

Few of August Rozental's paintings have survived, mainly due to the wartime events described above. The works that we can see are primarily paintings of a religious character. After all, these were artists' main source of income at the time, because a collector's market had not yet begun to function in Bulgaria. Current findings indicate that apart from works in the Alexander Nevsky Cathedral in Sofia his paintings can be found in orthodox churches in Batak and Peštera, as well as in the second orthodox church in the Kremikovski Monastery (Kremikovski Manastir). Rozental also designed and painted elements in iconostases in orthodox churches in the villages of Požarevo, Zvančevo, Pazardžik and elsewhere [11, 14, 26, 27]. We know that these works were considerably greater in number, but documenting them would require following appropriate procedures.

His best-known works are located in the Alexander Nevsky Cathedral, especially the tympanum situated over the northern entrance (fig. 3). This is a mosaic depicting three orthodox saints who lived in the region at the turn of the eleventh and twelfth century. From left to right, their names are: Joakim Osogovski, Gavril Lesnovski and Prohor Pčinski [9, 11, 12, 28].

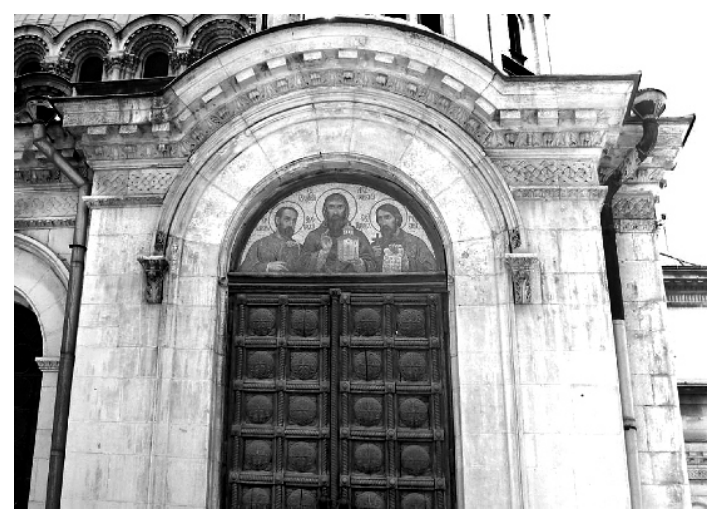

Figure 3. Tympanum - mosaic by August Rozental in Alexander Nevsky Cathedral (photo by author)

Many sources also refer to a fresco inside the cathedral located in a niche in the northern nave and entitled "crucifixion" (razpiâtie). At this location one does in fact find a fresco depicting a cross (albeit without Christ), beside which hover the heads of angels (as described by Rajna Kostenceva). But the figures standing next to the cross are St. Elena and the episcope of Jerusalem, Makarij, who discovered the aforementioned cross in Jerusalem in the $4^{\text {th }} \mathrm{c}$. AD. When asked, the local priest suggests (as does a note in the church guidebook) [12], that the painting is the work of I. M"rkvička [29]. This artist was Rozental's professor at the Academy and the one who invited him to join the group of artists tasked with decorating the church. Specialists are therefore needed to explain this matter.

The third work, which only the painter's wife describes [11], is a fresco on a cathedral balcony (not visible from the lower level) called "The Divine Cloth" (Obrus Gospoden). The fresco was restored, and its composition was changed in the process. However, the original oil painting, which Rozental entered in a contest (and won), is preserved in the National Orthodox $\mathrm{Mu}$ seum in Sofia. We were nevertheless unable to locate it during our investigation. Only afterwards did we find a footnote in the oft-cited book by Rajna Kostenceva [11] that somewhat explains the matter. The authoress claims that she spoke with the curator of the museum, personally drawing his attention to the fact that the painting in question had been mistakenly attributed to Nikola Petrov, and that this error should be rectified. She also added that Petrov's and Rozental's styles differ so greatly that a specialist should have no problem confirming her assertion.

Apart from the works mentioned here, August Rozental also won a competition for decorating the right wall of the aforementioned balcony, as well as for executing a different scene depicting Enravot, an uncle of Prince Boris I, who converted to Christianity much earlier than his sovereign. Officially, Bulgaria converted to Christianity with the baptism of Prince Boris I on May 25, 866 [24]. Competition sketches of these works have probably been preserved somewhere. A. Rozental never completed them as frescos. He did not have time, because once mobilization was declared during the Balkan War of 1912, he volunteered for the army and died in a battle against the Turks on November 22 of that same year at Seliolu-Gečkinli, near the town of Edirne. He was barely 37-years-old.

August may have had a premonition of what awaited him. Standing in the freight car amid soldiers traveling to the front, he said to his wife, “... a year from now I may be gone, and my unborn child may be without a father." His son, also named August, was born five months later [11].

We managed to find a single picture of August, of rather poor quality (fig. 4), in the collection of poems by Juliusz Rozental cited above [16]. However, according to his wife [11], August of- 
ten used himself as a model when painting icons of saints. Thus, by comparing various paintings of his and noting similarities among various figures, it would probably be possible to determine how he actually looked.

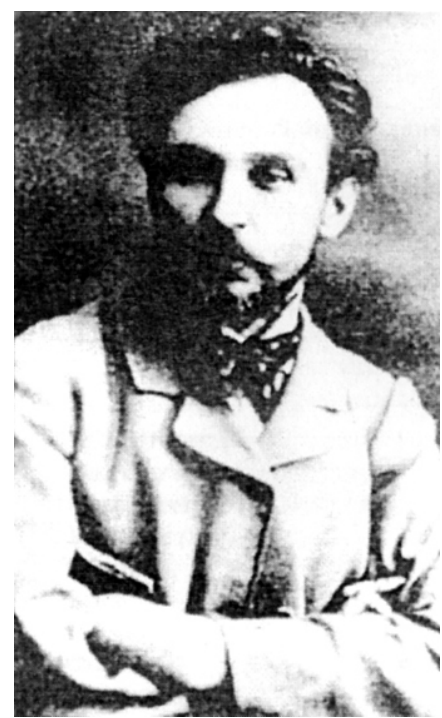

Figure 4. Photograph of August Rozental [16]

The death of August Rozental - a martyr's death, as he was captured after being wounded and underwent inhuman torture - has been described in depth in various Bulgarian publications. And not only Bulgarian: Wikipedia also contains an article in Russian [14] that mentions him, his work and his death. His name is also featured on a commemorative plaque located in the main hall of the Bulgarian Academy of Fine Arts. The plaque lists the names of graduates who died during the 1912 Balkan War and WWI (fig. 5). The name of our protagonist is second on the list.

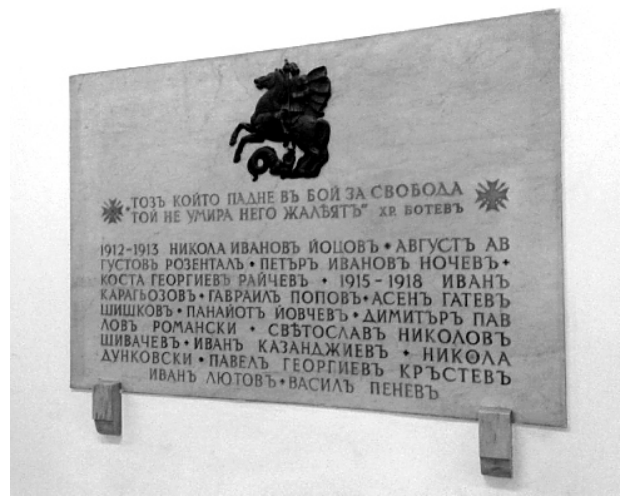

Figure 5. Memorial tablet with the names of graduates of DRU and NHA (including August Rozental) who died during the Balkan war in 1912 and WWI (photo by author)

\section{Discussion}

The whole Rozental family consisted of noteworthy figures who bound themselves to their new fatherland, literally "for death and life". At the same time, they all explicitly emphasized their Polish roots. The sons (August and Juliusz) were born in Siberia after their parents had been exiled there as punishment.
They probably never had a chance to see Poland. They died fighting "for our freedom and yours". Why then are they completely unknown in their own country - a country that, as the above stories make plain, they always held so dear? Especially in the case of August the painter, a thorough analysis and documentation of his works is surely in order. They still exist, and they deserve competent assessment by experts. At present, our knowledge of the subject is still fragmentary. But even now, Polish tourists traveling to Bulgaria and visiting the Alexander Nevsky Cathedral in Sofia should be provided with information by our travel agencies about a Polish artist responsible for icons of three saints in the tympanum above the entrance (on the right side) on the northern side of the church. Because they truly are impressive.

At the Institute of Art of the Polish Academy of Sciences in Warsaw, we obtained access in 2013 to materials [30] that had been submitted in 1994 by Z. Klejn (press correspondent to Bulgaria). These include Xeroxes of two sources that we were unable to find: Catalog of the Posthumous Exhibition of August Rozental, Sofia 1913 (Posm"rtna izložba na hudožnika Avgust Rozental, Sofiâ 1913) and an unsigned article entitled Avgust Rozental from the journal "Hudožestvena kultura" 1914 no. 32, which contain pictures of our protagonist, the tympanum in Alexander Nevsky Cathedral in Sofia and a study of a portrait of his wife Rajna. Is this enough material to ensure that August Rozental might someday be included in the Dictionary of Polish Artists [31]? That remains to be seen. This subject is under discussion at the Institute of Art of the Polish Academy of Sciences [30]. The materials mentioned above have not been included in the bibliography, because they were collected not by the author, but by Z. Klejn. However, they confirm the thesis that our protagonist was of Polish extraction, while also expanding our knowledge of his work.

\section{Conclusions}

This paper provides clear answers to the research questions posed in the introduction:

1. August Rozental came from a family whose members always emphasized their Polish roots. Apart from the fact that his contemporaries report our protagonist to have been Polish, the most compelling evidence is the student registry [6], clearly visible in figure 1 , and his wife Rajna's memoirs [11].

2. Source material containing information on the life and work of August Rozental can be found in the archives of the Fine Arts Academy in Sofia, and in the rector's office (memorial table, fig. 5), as well as in the books, periodicals and internet sites cited in the text.

3. The works of August Rozental, especially those of a religious character (decorating several orthodox churches and monasteries), are primarily located in and around Sofia [32, 33], the most important being those in Alexander Nevsky Cathedral. His remaining works, being of a secular character, are known from various catalogs and exhibitions. However, most of the originals were destroyed during the bombing of Sofia in WWII.

\section{Literature}

1. Kaczmarek U. (1993). A history of the Poles in Bulgaria. Poznań: Ars Nova. [in Polish]

2. Klejn Z. (2005). Bulgaria: sketches from recent history. Pultusk: Wyższa Szkoła Humanistyczna im. Aleksandra Gieysztora. [in Polish]

3. Wasilewski T. (1970). A history of Bulgaria. Wrocław, War- 
szawa, Kraków: Zakład Narodowy im. Ossolińskich. [in Polish]

4. Mazurkiewicz L. (2012). Selected tourism theories and research methods. Studies and Monographs no. 140, Warszawa: AWF Warszawa. [in Polish]

5. Interview with Georgi Mikov, Curator of the National Orthodox Museum in Sofia on 19.07.2013.

6. Student registry for the academic year 1876-1877. Academy of Fine Arts (Nacionalna hudožestvena akademiâ v Sofiâ), p. 1. [in Bulgarian]

7. http://www.blitz.bg/article/601. Retrieved 19.07.2013.

8. Takov R. (2012, May 31). The artist designed a flying bicycle. 24časa. [in Bulgarian]

9. Bakalova E. (2005, July 22). Alexander Nevsky cathedral. Kultura 22/2005. [in Bulgarian]

10. Encyclopedia “Bulgaria”. (1986). Volume 5. Sofia: Izdatelstvo na BAN. [in Bulgarian]

11. Kostenceva R. (2008). My hometown Sofia at the end of the $19^{\text {th }}$ and beginning of the $20^{\text {th }}$ century and after. Sofia: RIVA. [in Bulgarian]

12. St. Alexander Nevsky, Patriarchal Stavropegic Cathedral. (2013). Unicart. [in Bulgarian]

13. Modern Bulgarian encyclopedia. (1994). Volume IV a. Sofia: Izdatelstvo ELPIS. [in Bulgarian]

14. http://ru.wikipedia.org/wiki/Rozental'_Avgust_Avgustov. Retrieved 25.07.2013.

15. www.archives.bg/balkanwars/spisuci/2281-2012-07-08. Retrieved 25.07.2013.

16. Rozental Û. (2010). Songs half sung. Plovdiv: ASTARTA. [in Bulgarian]

17. Penčeva R. (2012). Poetic creativity of anarchist Ûlij Rozental. Literaturen Svât 38/2012. [in Bulgarian]

18. http://www.libblagoevgrad.org/publ/silianov/pdf/Silanov.p df. Retrieved 28.08.2013.
19. http://bg.wikipedia.org/wiki/Kategoriâ-polâci-v-B"lgaria. Retrieved 28.08.2013.

20. www.rastko.rs/rastko/delo/12576. Retrieved 28.08.2013.

21. Encyklopedia. (1984). Warszawa: PWN. [in Polish]

22. Interview with the director of the Emiliyan Stanev Museum in Veliko Tarnovo (Muzej Emilian Stanev v Veliko Tărnovo), Radka Penceva (Radka Penčeva), author of the introduction to the collection of poems by J. Rozental [17], 10.21.2013.

23. Dimitrovič B. (2008). Chinese medicine in Serbia and doctor Rozental case. Medicus 26/2008, p. 17. [in Serbian]

24. Dimitrov I. (Ed.) (1983). Concise history of Bulgaria. Sofia: Izdatelstvo Nauka i Izkustvo. [in Bulgarian]

25. Road Atlas EUROPA. (1992). Warszawa: Mercedes-Benz, Polskie Przedsiębiorstwo Wydawnictw Kartograficznych im. E. Romera. [in Polish]

26 http://www.artpice.bg/anta_details. Retrieved 19.07.2013.

27. http://www.pepatabakova.com/Articles. Retrieved 28.08.2013.

28. St. Alexander Nevsky - sanctuary-monument. (1924). D”ržavna Pečatnica. [in Bulgarian]

29. Protich A. (1955). I.V.Murkvichka-life and work.

30. Interview with Urszula Makowska-Pietkiewicz, manager of the "Dictionary of Polish Artists" section (Department of the History of Fine Art, Institute of Art of the Polish Academy of Sciences), 08.10.2013.

31. Dictionary of Polish artists (2013). Warszawa: Instytut Sztuki Polskiej Akademii Nauk.

32. http://wikimapia.org/19828733/bg. Retrieved 28.09.2013.

33. http://www.mapa-europy.com. Retrieved 28.09.2013.

Submitted: October 30, 2013

Accepted: January 30, 2014 